\title{
Virus-induced CXCL10-CXCR3 positive feedback loop via astrocytes is critical for maintaining chronic inflammatory lesions in HAM/TSP
}

\author{
Tomoo Sato ${ }^{1}$, Hitoshi Ando', Utano Tomaru², Mari Yoshida ${ }^{3}$, Atae Utsunomiya ${ }^{4}$, Junji Yamauchi ${ }^{1}$, Natsumi Araya', \\ Naoko Yagishita', Ariella Coler-Reilly ${ }^{1}$, Steven Jacobson ${ }^{5}$, Yoshihisa Yamano ${ }^{1 *}$
}

From 16th International Conference on Human Retroviruses: HTLV and Related Viruses

Montreal, Canada. 26-30 June 2013

HTLV-1-associated myelopathy/tropical spastic paraparesis (HAM/TSP) is a debilitating neurologic disorder characterized by chronic inflammation in the spinal cord. However, the precise mechanism by which chronic inflammatory lesions in HAM/TSP are formed and maintained has not been discovered. Since it is believed that chemokines play a central role in lymphocyte recruitment to sites of inflammation, we hypothesized that a positive feedback loop driven by chemokines may be responsible for the chronic inflammation in HAM/TSP. We aimed to determine the identity of these chemokines, where they are produced, and how they drive chronic inflammation in HAM/TSP. We found that HAM/TSP patients have extraordinarily high levels of the chemokine CXCL10 and an abundance of cells expressing the CXCL10-binding receptor CXCR3 in the cerebrospinal fluid. Histological analysis revealed that astrocytes are the main producers of CXCL10 in the spinal cords of HAM/ TSP patients. Co-culture of human astrocytoma cells with CD4+ T-cells from HAM/TSP patients revealed that astrocytes produce CXCL10 in response to IFN- $\gamma$ secreted by CD4+ T-cells. Chemotaxis assays results suggest that CXCL10 induces migration of peripheral blood mononuclear cells to the central nervous system (CNS) and anti-CXCL10 neutralizing antibody can disrupt this migration. In short, HTLV-1-infected cells in the CNS produce IFN- $\gamma$ that induces astrocytes to secrete CXCL10 that recruits more infected cells to the area via CXCR3, constituting a Th1-centric positive feedback loop that results in chronic inflammation.

\footnotetext{
* Correspondence: yyamano@marianna-u.ac.jp

'Department of Rare Diseases Research, Institute of Medical Science,

St Marianna University School of Medicine, Kawasaki, Kanagawa, Japan
}

Full list of author information is available at the end of the article

\section{Authors' details}

'Department of Rare Diseases Research, Institute of Medical Science, St Marianna University School of Medicine, Kawasaki, Kanagawa, Japan. ${ }^{2}$ Department of Pathology, Hokkaido University Graduate School of Medicine, Sapporo, Hokkaido, Japan. Institute for Medical Science of Aging, Aichi Medical University, Nagakute, Aichi, Japan. ${ }^{4}$ Department of Hematology, Imamura Bun-in Hospital, Kagoshima, Kagoshima, Japan. ${ }^{5}$ Viral Immunology Section, Neuroimmunology Branch, National Institutes of Health, Bethesda, MD, USA.

Published: 7 January 2014

doi:10.1186/1742-4690-11-S1-025

Cite this article as: Sato et al:: Virus-induced CXCL10-CXCR3 positive feedback loop via astrocytes is critical for maintaining chronic inflammatory lesions in HAM/TSP. Retrovirology 2014 11(Suppl 1):O25.

Submit your next manuscript to BioMed Central and take full advantage of:

- Convenient online submission

- Thorough peer review

- No space constraints or color figure charges

- Immediate publication on acceptance

- Inclusion in PubMed, CAS, Scopus and Google Scholar

- Research which is freely available for redistribution

Submit your manuscript at www.biomedcentral.com/submit
() Biomed Central 